\title{
IT INDUSTRY AS THE BASIS OF INNOVATIVE DEVELOPMENT ECONOMY OF UKRAINE
}

Formulation of the problem. The current stage of development of the world economy is characterized by accelerated rates of scientific and technological progress and increasing intellectualization of the main factors of production. The development of a country and its level of competitiveness in the world market depends on the innovative activity of the subjects of the national economy. Nowadays, scientific knowledge and information resources are an important information and communication resource of the economy. The system of relations of modern society is turning in the direction of more efficient work with information.

The social significance of any process is determined not only by the availability of resources, production conditions, capital or money, but also by the availability of information resources, scientific knowledge and information. Priorities in industrial relations are shifting to scientific knowledge and information. In modern economy, social significance depends on the information essence, that is, the awareness of the subject or the saturation of its information flows. Public and economic power is shifted not to the owners of tangible capital but to the owners of information that is educational about how to make the most of the wealth in today's economy. Today, the richest people in the world are those involved in the information business.

Analysis of recent research and publications. The high degree of influence of information on modern socio-economic processes is emphasized by many researchers. Information economy in a narrow sense means "the aggregate of industries related to information production and logistics of this process" [1, p. 74]. In the broad sense of IE, it is seen as a component of IP, in which "socio-economic development depends, first of all, on the production, storage and dissemination of information among members of society" [2, p. 35], and productivity gains in the "new" economy, in turn, are driven by technological advances in information processing and transmission. Considerable contribution to the research of problems of innovative activity was made by such domestic and foreign scientists as A. Galchinsky, V. Geyets, M. Dolishny, A. Savchenko,
M. Delyagin, V. Inozemtsev, E. Sparrow, B. Haywood, E. Jordan et al. However, in our opinion, the scale and level of scientific research of the problem of activation of innovative activity of domestic enterprises remain insufficient. This is evidenced by the low level of innovation component in economic processes.

The purpose of the article is to investigate information aspects of innovation and identify ways to overcome the contradiction between the high innovative potential of Ukrainian IT specialists and the low level of innovative development of Ukraine.

Outline of the main research material. In the information economy, economic activity is manifested mainly in the production and use of accumulated information and advanced information technologies to improve the efficiency and profitability of other forms of production and ensure economic growth, as well as the accumulation of information capital and wealth (information products and services).

Limiting factors in this case are information, scientific knowledge, intelligence and human capital. Thus, economic and political power passes to the owners of information and the means of its reproduction. Business success is beginning to be driven by involvement in global information, communication and digital networks. The information paradigm is based on the following fundamental position: the substance of various socio-economic phenomena and processes is information and communication processes and all their manifestations. Various political, social, psychological, and economic phenomena (processes) have an informational nature or an information-based genetic basis.

Information dynamics have both economic dynamics and dynamics of social processes. If we consider the information criterion (the method of collecting, producing, analyzing, using appropriate information and managing information processes in society) as a systematic principle and basis for reproduction, then we can develop a classification of stages or stages of development of human civilization. Each of these stages is closely interdependent with the change in the modes of reproduction that accompany the expediency of the in- 
formation determined by the evolution of the technological basis of the reproduction of society.

In order to carry out the process of reproducing their diverse social life, and, above all, the socio-economic one, people enter into certain relationships and relationships, within the framework of those forming a single coherent system, there is their relation to the world and nature. Agreeing with S. Dyatlov, we note: "Relations and relations of this kind are informational in nature, that is, the combination of all relationships between people about the reproduction of their multifaceted social life is an information interaction, exchange of information, formation, its accumulation, production, analysis, selection and consumption" $[3$, p.79]. In the information society, the structure of creative productive human forces is actualized in the form of human information resources (information needs and abilities). In an information society, a person is a multifaceted personality as the decisive creative factor and the main information resource of society. In the modern socio-economic system of a new type, which has an extremely complex structural and functional organization, a person performs various functions, plays a variety of social roles. Within the information paradigm of socio-economic development [3], that reproduction is a system of wholly organized structures and elements that functions and develops in accordance with objective laws of expression. In such a system, the exchange of information, energy and matter with the external environment cannot occur freely and spontaneously, but is carried out within the boundaries determined by the conscious goals and interests of development and determined by the type, level, type and form of its concrete existence. The increasing role of information in socio-economic development and its acceleration on this basis has led to the socio-technical process of informatization of society. As a social phenomenon, informatization acts in the form of social activity, focused on the ultimate goal - the transformation of humanity into an information civilization with a humanistic and rational social system. The essence of this activity lies in the mastery of social information as the most important resource of development by means of informatics [4, p.45].

To reflect post-industrial development, Bell proposed to apply traditional indicators of economic development, such as GNP, and to revise the system of national accounts (SNA) in terms of costs and benefits.

"The system of national accounts should begin with a series of social indicators, which should give us a broader and more balanced account of economic progress in the sense in which we understand it" [5, p. 116]. Bell believed that efforts to create a system of national accounts should be aimed at achieving four major goals: a) measuring the social costs and benefits of innovations; b) measurement of social illnesses (ie crime, divorce); c) creation of "budgets achieved" to identify social needs (ie, housing, education); d) search for indicators of economic opportunities and social mobility.

The appropriateness of accounting in the system of national accounts of social needs can be confirmed by the studies of J. Keynes [6, p.103-110], dedicated to identifying the main incentives or goals (aspirations) that encourage people to refrain from spending received funds and are subjective. A. Marshall [7, p.117] wrote about the expediency of including in the SNA the analysis of peculiarities of behavior of economic entities. This proposal is relevant today and has developed in modern world practice in accordance with the UNSR project, approved in 1993 [8]. The calculation of GDP is carried out by three methods: production, distribution and end use (Table 1).

At the same time, intangible services are being introduced into the new conceptual model of inter-industry balance (IMB) $[9, \mathrm{p} .12]$.

\section{Methodological bases for building the system of national accounts (SNA) and balance of national economy (BNG) \\ (developed by the authors on the basis of source [9])}

\begin{tabular}{|l|l|}
\hline \multicolumn{1}{|c|}{ Principles of construction of the SNA } & \multicolumn{1}{|c|}{ BNG construction principles } \\
\hline $\begin{array}{l}\text { Marxist conception of the interpretation of social production, } \\
\text { according to which material production plays a key role in } \\
\text { the structure of social production. It participates in the crea- } \\
\text { tion of the aggregate social product (CSP) and national in- } \\
\text { come (ND). }\end{array}$ & $\begin{array}{l}\text { Extended interpretation of social production, according to } \\
\text { which all branches of material and intangible production take } \\
\text { part in the production of national income }\end{array}$ \\
\hline $\begin{array}{l}\text { The primary is the income of workers in the sphere of mate- } \\
\text { rial production (distribution). All other categories of em- } \\
\text { ployees form the secondary income structure resulting from } \\
\text { the redistribution }\end{array}$ & $\begin{array}{l}\text { Any economic activity that generates income for the subjects } \\
\text { of such activity is considered productive. That is, the crite- } \\
\text { rion of productivity is income. Primary income is treated as } \\
\text { that resulting from the primary distribution of GDP and in- } \\
\text { cludes the income of all economic entities. }\end{array}$ \\
\hline $\begin{array}{l}\text { The result of viral performance is formed not less than the } \\
\text { product of the end, but of the longest living in the sphere of } \\
\text { material production }\end{array}$ & $\begin{array}{l}\text { The result of production activity is the final product of all } \\
\text { sectors of the economy }\end{array}$ \\
\hline
\end{tabular}

There is a trend toward transition to the CHP, a technique of folding a singing order to see the traditional balance sheet (Table 1) to join the Ukrainian economy.
With the reorientation of the economic system of Ukraine from plan-command to market principles of management, the previously used balance of the na- 
tional economy (BNG) ceased to meet the growing needs of economic and economic agents in information. This led to the expediency of moving to a new form of accounting and calculation of macroeconomic indicators.

You can see the three main groups of factors that can be used to develop productive forces, suspension institutions, enriching the formulas of new minds of the state, and the development of the economy [10, p. 78-79]:

1. I'm persuading a group of technological factors. The price is enriched by the emergence of new technologies - information technology, computer technology, computer technology, and so on.

2. It is possible to introduce social and economic factors to other groups, as well as related to the institutional and social transformations.

The third group should include the factors that determine the strengthening of socialization of the economy in the current NTP. A significant impetus to the formation of the information economy is the development of the intellectual potential of society, for the successful formation of which it is expedient to introduce such principles as [11, p.119-124]: freedom of creativity; inviolability of intellectual property; non-opposition of the intellectualization of society to the general progressive changes, their synchronization and complementarity; establishing interconnection and conformity of intellectualization and informatization; the creation of new warehouse structural assimilation on the basis of intellectual capital; the fate of the country is active in the international cooperation.

Along with the process of intensification of information production, there is a problem of information culture, which E. Semeniuk defines as the level of practical achievement of "information interaction and all information relations in society, a measure of perfection in the operation of any necessary information" [12, p. 2]. In this case, M. Kolyada [13, p. 22] distinguishes between the information culture of relations and the information culture of knowledge. The increase in the status of the central understanding of the information economy is enriched by the active change of minds of sociallyeconomic development, the average of some clearly progressive productive forces, and the increase in the concentration of scientific and technical progress on economic processes,

The main significance of science and information factors in all areas of social welfare, the increase in the speed of informatization and economic suspension, as a result, the transition to a new stage of social and economic organization.

To imbalance in the development of small warehouses of innovation and the factors of efficiency and effectiveness of the economy, Seminozhenko's respect [14]. There is a need to understand that everything that needs to be spent on human resources - to educate, expressively qualify personnel, the market for patent activity of the population, patent science infrastructure is lost in the long term.
However, the institutional organization of warehouses, including the number of companies acquired before the innovation processes, the competitiveness of the internal market, the regulatory environment, there is little to do with the innovation of the whole world. The leading role in the transition of Ukraine to the innovation rails is development in the IT sphere. The main part of the Ukrainian IT market is outsourcing - transferring to one company of singing processes, but the function to the weekend of the company, so much is competent. In addition, it seems, outsourcing companies to test that robot, but you should be able to do it anyway; The main deputies for the outsourcing of outsourcing companies are the main company.

In the field of software security support for IT outsourcing, Ukraine is the leader in Central and International Europe. What is meant by foreign scholars to hinder pressure for Ukrainian programmers is not a different development cycle, but a viola outsourcing, but a lesser part of the deal. The line of offshore outsourcing in Ukraine is explained by the decile factors. One of them is the development of information technology and communication, allowing small companies to join small companies, and the high-tech Internet technology and security service. The final factor was a seemingly low price of labor in Ukraine, which was added to the highest level of qualification.

Finally, the third factor was the low level of demand for Ukrainian programmers by Ukrainian companies, as well as ill-considered tax policy. Therefore, the best professionals are forced to offer their services outside the country. The main consumers of IT services in Ukraine are the USA and Western Europe. Orders are made mainly in English and German. The programs developed in Ukraine are used in the information systems of the world's largest corporations, banks, and in the billing systems of leading telecom operators. The software developer is known only to the customer and the copyright is the customer. The reason for the rapid development of offshore outsourcing in Ukraine is the weak internal demand and high level of IT services provided by Ukrainian professionals. The geographical location of outsourced enterprises is mainly located in cities with one million inhabitants. However, trends are gradually changing and outsourcing businesses are beginning to emerge in areas and areas. As a rule, this concerns outsourcing companies that provide services only in Ukraine and employees who can outsource services only in Ukrainian and Russian.

The largest number of outsourcing companies is registered in Kyiv and Kharkiv. In Kyiv, as a rule, outsourcing companies seek to enter international and European markets. And, as a consequence, the main requirement for employees is fluent in foreign languages, since outsourcing services are already provided exclusively in foreign languages. Therefore, the highest salaries of employees working at outsourcing companies in Kyiv compared to regions. With the entry into force of the Law of Ukraine "On Limited and Additional Liabi- 
lity Companies" of February 6, 2018 No. 2275-VIII, there are certain restrictions in the conclusion of contracts. The members of a limited liability company are liable within the limits of their contribution. The company is responsible by his obligations to all his property.

Outsourcing companies are usually created by individuals. The number of such participants is one or two. The maximum number of founders is 5 . Sometimes there are cases when legal entities set up outsourcing companies by investing their own share in the authorized capital. LLC "ITY OUTSOURCING UKRAINE" has the largest authorized capital (15625798,9 UAH). The second place by the size of the authorized capital is held by AK "PIESPUTSORSING" LLC, with the authorized capital $11728667.60 \mathrm{UAH}$. The third step was taken by ALFA OUTSOURCING LLC, whose share capital amounts to $8383000,00 \mathrm{UAH}$. All three societies are located in Kyiv. In the above outsourced companies founders: individuals and legal entities. Founder of LIGHTFIELD STUDIOS INC. At ITE OUTSOURCING UKRAINE LLC (USA) and the final beneficiary is an individual (Republic of Cyprus). IN AK "PI. PIAUTSORSING" founder - Limited Liability Company "CONSULTING COMPANY" PI. PIP CONSULTING ". The founder of "ALFA OUTSOURCING" LLC is a privately owned enterprise "ST TRUST". The areas of outsourcing activity under the existing CEAs of the three leaders of outsourced enterprises in terms of authorized capital are as follows: 62.01 - Computer programming; 69.20 - Accounting, bookkeeping and auditing activities; tax consultancy 46.90 - Non-specialized wholesale trade. For any outsourcing enterprise in Ukraine, the system of taxation is essential for its stable existence [16]. Conducting outsourcing analysis, obtaining information from the official Payer Register and the Single Payer Register, the maximum number of out going payments is limited to the public (fig. 1).

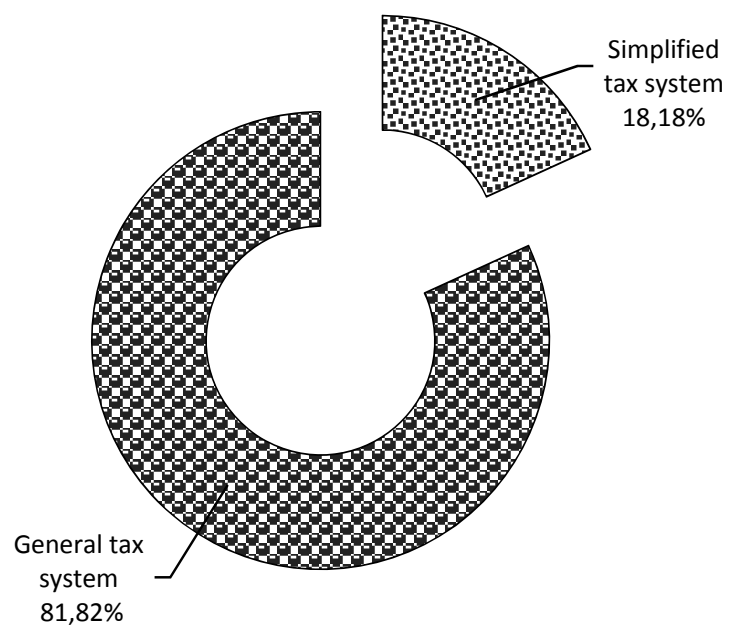

Fig. 1. The system of subsiding, so as to rob outsourcing of enterprises in advance to the tax code of Ukraine

(scribbled by the authors on the basis of sources [15])
Outsourcing enterprises, as a rule of thumb, state support, as a rule, by payers of personal income taxes, but in fig. 2 of these enterprises total $25.17 \%$ of the total number of residents. So, for example, from 2016 TOV "IT OUTSOURCING UKRAINE" registrations yak payer PDV.

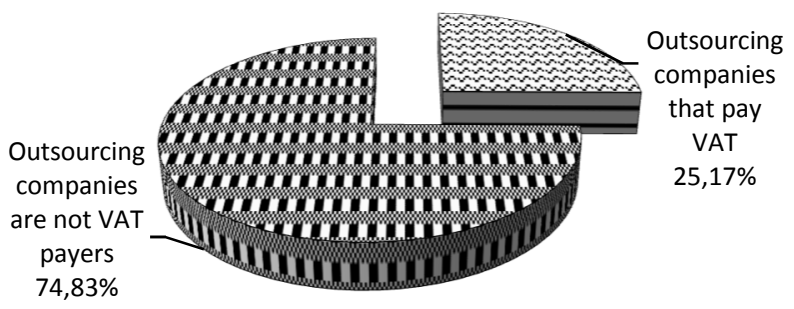

Fig. 2. Outsourcing enterprises, such as PDV

in business camps for 2019 (insured by authors on the basis of sources [15])

Repaired from 2004 to 2019 the number of outsourcing enterprises - payers of personal income taxes (fig. 3) At 2019 the number of outsourcing enterprises payers PDV stockpiled 36.

26 outsourcing companies have bored registered like VAT payers, however, for the present hour they have turned around for a simplified system for roll-back, but they have forgotten for an out-of-band system for roll-back, but they canceled the restoration of a paid pay-as-you-go system. C Clear the first and foremost anonymous registration of MPEs: canceled for independent decision-making body ( 6 outsourcing companies), canceled for payer initiation (20 outsourcing companies). The main reasons for the impairment of MPE are the availability of supplies and the lack of declaration. The average duration of outsourcing as a VAT taxpayer is more than four years. For example, AKYUMEN OUTSOURCING LLC was registered as a VAT payer for over 14 years [17]. Only four outsourcing companies were VAT payers for more than a year (OUTSORSING YUY LLC, PE GSISM, YURIDICHNAYA KOMPANIYA "PREOGATYVA", DENISOV LLC CAMPAIGN OUTSOURCING, OUTSOURCING INTERNATIONAL LTD.).

At the same time, $18.18 \%$ of outsourcing outfits are robbed of a simplified pay-as-you-go system. In 2019, the number of outsourced businesses that opted for a simplified taxation system was 25 . These businesses pay a single tax at a rate of five percent and are in the third group in accordance with the requirements of the Tax Code of Ukraine [17]. The world of information technology is changing rapidly, as demand for service providers is changing as well, and the pace of outsourcing market development is gradually increasing. New forms of customer-outsourcing interaction are blurring the boundaries and opening up new opportunities for outsourcers as well as their employees. One of the positive features of outsourcing is the ability to constantly improve skills in order to be competitive in the market and the prospect of fully discovering your talent, including outside the country. 


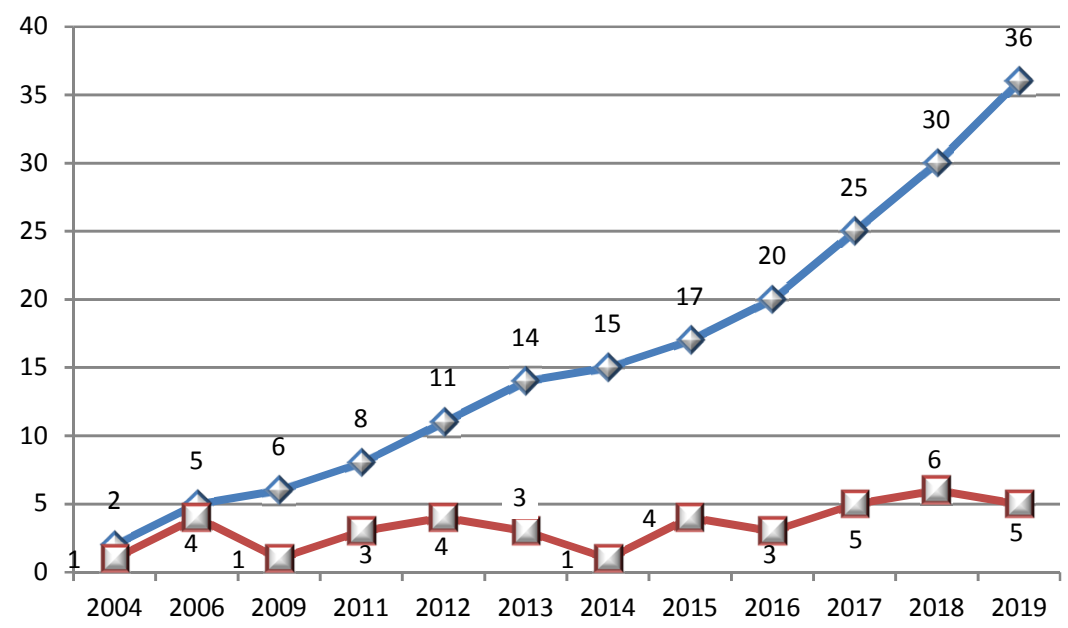

$\rightarrow$ Number of outsourced companies registered as VAT payers by year

- Number of outsourced companies that continue to carry on business since VAT registration

Fig. 3. Dynamics of increase in the number of outsourcing companies - VAT payers

(patched by the authors on the basis of sources [15])

Conclusions. A key prerequisite for innovating in the IT industry is having an effective marketing system that connects the enterprise with the end consumer of the service, in order to constantly identify new explicit and hidden consumer needs for the quality of this service. This condition is crucial because only innovations that give the end user new benefits are successful. The decision to use outsourcing is always a risk, and the reality of receiving immediate benefits in the form of cost reductions raises considerable doubts. That is why the success of the enterprise's developed measures depends to a certain extent on the feedback and the current monitoring system.

Thus, it is worth highlighting the following areas of development of the IT industry in Ukraine:

1. Ensuring transparency and openness of the IT market, facilitating the emergence of a significant number of public projects.

2. Development of regulations, standards and normative framework that helps to maintain long-term relationships between the supplier and the customer of the software. pants.

3. Providing legal protection for IT market partici-

4. Creation of basic infrastructure for the opening of R\&D centers (research and development).

5. Creating the conditions for the mass appearance of startups, and later large product companies.

\section{Literature}

1. Шуть О. Н. Информация и ее роль в экономике: дис. ... канд. экон. наук: 08.00.01 / Санкт.-Петербург. гос. ун-т. СПб., 2004. 150 с. 2. Негодаев И. А. На путях к информационному обществу. Ростов н/Д. : ДГТУ, 1999. 247 с. 3. Дятлов С. А. Принципы информационного общества. Информационное общество. 2000. Вып. 2. С. 77-85. 4. Урманцев Ю. А. Эволюционика или общая теория систем природы, общества, мышления. Москва : Пущино, 1988. 354 с. 5. Bell D. Notes on the Post-Industrial Society. The Public Interest. N.Y. : National Affairs. 1967. № 7. Р. 116. 6. Кейнс Дж.
Общая теория занятости, процента и денег. Москва : Гелиос АРВ, 2002. 352 с. 7. Маршалл А. Принципы политической экономии / пер. с англ.; общ. ред. и вступ. ст. С. М. Никитина. Москва : Иностр. лит-ра, 1993. T. 1.526 c. 8. System of National Accounts 1993. Commission of European Communities International Monetary Fund, Organization for Economic Co-operation and Development, United Nations, World Bank. Brussels, Luxembourg, New York, Paris, Washington D.C., 1993. 9. Kaмешева Н. В. Національні рахунки України: становлення, розвиток та перспективи. Актуальні проблеми економіки. 2003. № 5(23). С. 10-16. 10. Гасанов Э. А. Факторы, условия и закономерности информационного типа экономического роста. Хабаровск : Изд-во ХГТУ, 2000. 246 с. 11. Экономика: свобода и солидарность. Москва: Наука, 1991. 197 с. 12. Семенюк Э. П. Информатизация общества, культура, личность. НТИ. Сер.1 : Организация и методика информационной работы. 1993. № 1. С. 1-7. 13. Коляда М. Г. Формирование информационной культуры будущих экономистов в процессе профессиональной подготовки : дис. ... канд. пед. наук / Донец. ин-т социального образования. Донецк, 2003. 289 с. 14. Семиноженко В. П. Возможен ли в Украине инновационный прыжок? Зеркало недели. Украина. № 17. С.5-6. 15. Саінчук А.О. Адаптація національної господарської системи до процесів глобалізації. Економічний вісник Донбасу. 2019. №2(56). C. 135-144. doi: 10.12958/1817-3772-20192(56)-135-144. 16. 18 украинских компаний-аутсорсеров попали в мировой ТОП-100. URL: https://dou.ua/ lenta/news/outsourcing-top-100-2018/. 17. Матвій I. С. Особливості розвитку IT-аутсорсингу в Україні. Вісник Національного університету "Львівська політехніка". 2013. № 754: Проблемиекономіки та управління. C. 185-190. URL: http: //ena.lp.edu.ua:8080/bitstream/ ntb/ 23516/1/27-185-190.

\section{References}

1. Shut' O. N. (2004). Informatsiya i yeye rol' v ekonomike [Information and its role in the economy]. Candidate's thesis. Saint Petersburg, St. Petersburg. state university [in Russian]. 
2. Negodayev I. A. (1999). Na putyakh k informatsionnomu obshchestvu [On the Ways to the Information Society]. Rostov-on-Don, DSTU. 247 p. [in Russian].

3. Dyatlov S. A. (2000). Printsipy informatsionnogo obshchestva [The principles of the information society]. Informatsionnoye obshchestvo - Information society, Issue 2, pp. 77-85 [in Russian].

4. Urmantsev Yu. A. (1988). Evolyutsionika ili obshchaya teoriya sistem prirody, obshchestva, myshleniya [Evolutionics or the general theory of systems of nature, society, thinking]. Moscow, Pushchino [in Russian].

5. Bell D. (1967). Notes on the Post-Industrial Society. The Public Interest, № 7, p. 116.

6. Keynes J. (2002). General Theory of Employment, Interest, and Money. Moscow, Helios ARV. 352 p. [in Russian].

7. Marshall A. (1993). Principles of Political Economy. Trans. from English; total ed. S. M. Nikitina. Moscow, Inostr. literature, 1993. Vol. 1. 526 p. [in Russian].

8. System of National Accounts 1993. Commission of European Communities International Monetary Fund, Organization for Economic Co-operation and Development, United Nations, World Bank. Brussels, Luxembourg, New York, Paris, Washington D.C., 1993.

9. Kamesheva N. V. (2003). Natsionalni rakhunky Ukrainy: stanovlennia, rozvytok ta perspektyvy [National accounts of Ukraine: formation, development and prospects]. Aktualni problemy ekonomiky - Current problems of the economy, 5(23), pp. 10-16 [in Ukrainian].

10. Hasanov E. A. (2000). Factors, conditions and patterns of the information type of economic growth. Khabarovsk, Publishing House of KSTU [in Russian].

11. Economics: freedom and solidarity. (1991). Moscow, Nauka [in Russian].

12. Semenyuk E. P. (1993). Informatizatsiya obshchestva, kul'tura, lichnost' [Informatization of society, culture, personality]. NTI. Ser. 1 : Organizatsiya i metodika informatsionnoy raboty - NTI. Ser.1: Organization and methodology of information work, 1, pp. 1-7 [in Russian].

13. Kolyada M. G. (2003). Formirovaniye informatsionnoy kul'tury budushchikh ekonomistov $\mathrm{v}$ protsesse professional'noy podgotovki [Formation of the information culture of future economists in the process of training]. Candidate's thesis. Donetsk, Donetsk Institute of Social Education [in Russian].

14. Seminozhenko V.P. Is an innovative leap possible in Ukraine? Mirror of the week. Ukraine, 17, pp. 5-6 [in Russian].

15. Sainchuk A.O. (2019). Analiz rynku autsorsynhovykh pidpryiemstv v Ukraini [Analysis of the market of outsourcing enterprises in Ukraine]. Ekonomichnyi visnyk Donbasu - Economic Herald of the Donbas, 2(56), pp. 135-144. doi: 10.12958/1817-3772-2019-2(56)-135144 [in Ukrainian].

16. 18 ukrainskikh kompaniy-autsorserov popali v mirovoy TOP-100 [18 Ukrainian outsourcing companies hit the world TOP-100]. Retrieved from https://dou.ua/ lenta/news/outsourcing-top-100-2018/ [in Russian].

17. Matvii I. Ye. (2013). Osoblyvosti rozvytku ITautsorsynhu v Ukraini [Features of the development of IT outsourcing in Ukraine]. Visnyk Natsionalnoho universytetu "Lvivska politekhnika", 754: Problemyekonomiky ta upravlinnia, pp. 185-190. Retrieved from http: //ena.lp.edu.ua:8080/bitstream/ntb/23516/1/27-185-190 [in Ukrainian].

Волошина О. О., Володченко В. В., Шашко В. О. ІТ-галузь як основа інноваційного розвитку економіки України

У статті визначено основні інформаційно-комунікаційні ресурси та резерви національної економіки, що дозволило обгрунтувати феномен інформатизації, який виступає у вигляді соціальної діяльності на шляху світового суспільства до інформаційної стадії розвитку. Розглянуто причини протиріччя між значним інноваційним потенціалом і низьким рівнем інноваційного розвитку економіки України. Визначено позитивні та негативні сторони аутсорсингу, обгрунтовано напрямок розвитку IT. Запропоновано шляхи для активізації інноваційної діяльності в Україні.

Ключові слова: інформаційно-комунікаційні ресурси, соціально-економічний розвиток, економіка, інформація, інновації, IT, аутсорсинг, оподаткування.

Voloshina O., Volodchenko V., Shashko V. IT Industry as the Basis of Innovative Development Economy of Ukraine

The article defines basic information and communication resources and resources of national economy which allows to explain the phenomenon of informatization that appears as a social activity on the way of global community to the informative stage of development. Interprets the reasons for the contradiction between the significant innovational potential and low innovative development of economics of Ukraine. Positive and negative aspects of outsourcing are identified, the development direction of IT is explained. The ways to foster innovation in Ukraine are suggested.

Keywords: information and communication resources, social and economic development, economy, information, innovation, IT, outsourcing, taxation.

Волошина Е. А., Володченко В. В., Шашко В. А. ІТ-отрасль как основа инновационного развития экономики Украины

В статье определены основные информационнокоммуникационные ресурсы и резервы национальной экономики, что позволило обосновать феномен информатизации, который выступает в виде социальной деятельности на пути мирового общества к информационной стадии развития. Рассмотрены причины противоречия между значительным инновационным потенциалом и низким уровнем инновационного развития экономики Украины. Определены положительные и отрицательные стороны аутсорсинга, обосновано направление развития IT. Предложены пути для активизации инновационной деятельности в Украине.

Ключевые слова: информационно-коммуникационные ресурсы, социально-экономическое развитие, экономика, информация, инновации, IT, аутсорсинг, налогообложение.

Received by the editors: 02.12.2019

and final form 19.12.2019 